\title{
Ocena zdrowotności materiału nasiennego traw w zależności od wybranych zapraw nasiennych
}

\author{
Estimation of the seed health of sowing material of grasses \\ in dependence of selected seed treatments
}

\section{Barbara Wiewióra®, Dagmara Bronisz}

Zakład Nasiennictwa i Nasionoznawstwa

Instytut Hodowli i Aklimatyzacji Roślin - PIB,

$\bowtie$ e-mail: b.wiewiora@ihar.edu.pl

\begin{abstract}
Celem pracy było określenie wpływu wybranych zapraw nasiennych na zdrowotność nasion traw: kostrzewy łąkowej i życicy trwałej z trzech kolejnych lat zbioru, otrzymanych od hodowców. Materiał do badań stanowiły nasiona czterech odmian kostrzewy łąkowej (Festuca pratesis) i czterech odmian życicy trwałej (Lolium perenne). Badano materiał siewny traktowany czterema zaprawami: dwie biologiczne Bioczos (ekstakt z czosnku) i Polyversum (oospory grzyba Pythium oligandrum) i dwie chemiczne Maxim (substancja aktywna: fludioksonil) i Vitavax (substancja aktywna: karboksyna i tiuram) oraz nasiona niezaprawiane, powierzchniowo odkażone podchlorynem sodu. Nasiona badanych gatunków i odmian były licznie zasiedlone przez grzyby zarówno saprotroficzne: Alternaria alternata, Aureobasidium pullulans, Epicoccum purpurascens i Penicillium spp. jak i patogeny: Fusarium spp. oraz Drechslera spp. i Bipolaris sorokiniana. Stwierdzono, że zastosowanie zapraw chemicznych, zwłaszcza użycie zaprawy Vitavax wpływa pozytywnie na poprawę zdrowotności wyrażoną liczbą kolonii grzybowych, w tym głównych patogenów. Nie obserwowano jednak znaczącej poprawy zdolności kiełkowania badanych nasion.
\end{abstract}

Słowa kluczowe: grzyby, patogeny, trawy, zaprawianie, zdrowotność nasion

\begin{abstract}
The aim of the study was to determine the effect of selected seed treatments on the health of grass seeds: meadow fescue and perennial ryegrass from three years of harvest, obtained from breeders. The material for the research was the seeds of four varieties of meadow fescue (Festuca pratensis) and four varieties of perennial ryegrass (Lolium perenne). Seed material treated with four treatments: two biological Bioczos (garlic extract) and Polyversum (oospores of the fungus Pythium oligandrum) and two chemical Maxim (fludioxonil) and Vitavax (carboxin and thiuram) and the untreated grain, surface disinfected with sodium hypochlorite. Seeds of the studied species and cultivars were colonized by both saprotrophic fungi: Alternaria alternata, Aureobasidium pullulans, Epicoccum purpurascens and Penicillium spp. as well as pathogens: Fusarium spp., Drechslera spp. and Bipolaris sorokiniana. It was found that the use of chemical treatments, especially the use of Vitavax, has a positive effect on the improvement of seed health expressed by the number of fungal colonies, including the main pathogens. However, no significant increase in the germination capacity of the tested seeds was observed.
\end{abstract}

Key words: fungi, grasses, pathogens, seed health, treatments.

\section{Wstęp}

Na wartość siewną nasion roślin rolniczych ma wpływ wiele czynników, a jednym z nich jest stosowanie różnych substancji aktywnych zarówno chemicznych, jak i biologicznych do zaprawiania materiału nasiennego (Sharma i in., 2015). Zaprawianie jest jednym $\mathrm{z}$ najczęściej stosowanych zabiegów uszlachetniania nasion, polegający na pokrywaniu powierzchni nasion różnego rodzaju substancjami tj. insektycydami, fungicydami, substancjami wzrostowymi itd., połączonymi z nasionami przy pomocy innej substancji (Kumar S., 2012; Forsberg i in., 2003). Przed zaprawianiem powinna być wykonana ocena fitopatologiczna, w celu identyfikacji grzybów, gdyż znajomość patogenów przenoszonych wraz z nasionami danego gatunku jest niezbędna do właściwego doboru zaprawy. Patogeny przenoszone z nasionami stanowią niebezpieczeństwo dla siewek i roślin, ponieważ są wprowadzane do gleby, gdzie w sprzyjających warunkach rozwijają się i atakują roślinę, a także stanowią źródło infekcji dla sąsiednich upraw. Większość z nich powoduje objawy plamistości liści ograniczające asymilację i wpływające na przyśpieszenie transpiracji (Kutrzeba, 1994b). Niekorzystny wpływ na te procesy skutkuje przedwczesnym zasychaniem liści, opóźnionym rozwojem roślin, czy pogarszaniem ilości i jakości paszy w przypadku traw o przeznaczeniu pastewnym. W przypadku wykorzystania trawnikowego takie zmiany są niekorzystne, gdyż użytkownikom 
zależy na ładnie wyglądającym trawniku, a wystąpienie przebarwień, czy plam nie wpływa na jego estetyczny wygląd (Prończuk, 1996). W użytkowaniu pastewnym obecność patogenów grzybowych np. Fusarium spp. również nabiera znaczenia. Chociaż nie są one powszechnie kojarzone z systemami karmienia opartymi na paszach, to jednak stwierdzono, że toksyny fuzaryjne mają znaczenie dla wypasanych zwierząt w Nowej Zelandii (Di Menna i in. 1987, 1991). Są one powiązane z upośledzoną płodnością owiec czy osłabieniem płodności maciorek (Smith i in., 1990). Przesłanki te skłoniły autorów do podjęcia badań dotyczących zdrowotności materiału siewnego, a zwłaszcza identyfikacji obecnych na nasionach patogenów grzybowych oraz możliwości poprawy tego parametru przy zastosowaniu zaprawiania nasion.

\section{Materiały i metody}

Materiał badawczy stanowily nasiona czterech odmian kostrzewy łąkowej (Festuca pratensis): Pasja, Wanda, Artema i Fantazja i czterech odmian życicy trwałej (Lolium perenne): Flinston, Baronka, Rela i Malowana ze zbioru w latach 2014, 2015 i 2016. Badania fitopatologiczne oraz ocenę zdolności kiełkowania wykonano na nasionach zebranych w trzech kolejnych latach, które zaprawiono zaprawami biologicznymi i chemicznymi: Bioczos (ekstakt z czosnku), Polyversum (oospory grzyba Pythium oligandrum), Maxim (s.a. fludioksonil) i Vitavax (s.a. karboksyna i tiuram) oraz nasiona niezaprawiane, powierzchniowo odkażane podchlorynem sodu. Zaprawianie nasion zarówno zaprawami biologicznymi, jak i chemicznymi wykonano zgodnie z zaleceniami producenta. Nasiona niezaprawiane odkażano powierzchniowo w $1 \% \mathrm{NaClO}$ przez 10 minut, a następnie trzykrotnie płukano w sterylnej wodzie. Zabieg ten miał na celu zmniejszenie liczby szybko rosnących saprotrofów zanieczyszczających powierzchnię nasion. Grzyby te mogłyby uniemożliwić wzrost $\mathrm{i}$ identyfikację patogenów, których liczebność była miarą skuteczności danej zaprawy.

Analizę zdrowotności przeprowadzono na 200 nasionach każdej odmiany dla nasion zaprawianych czterema wyżej wymienionymi zaprawami oraz nasionach niezaprawianych, powierzchniowo odkażonych. Nasiona wszystkich opisanych wyżej kombinacji wykładano po 10 sztuk na płytki Petriego z pożywką agarowo-ziemniaczaną (PDA). Inkubację przeprowadzano $\mathrm{w}$ termostacie o stałej temperaturze $20^{\circ} \mathrm{C}$ i oświetleniu NUV $360 \mathrm{~nm} 12$ h/12 h ciemności. Wyrosłe kolonie grzybów oznaczano do gatunku po $15-20$ inkubacji w podanych wyżej warunkach, stymulujących zarodnikowanie. Wyosobnione grzyby identyfikowano posługując się opisami grzybów zawartymi w opracowaniach: Barnett (1960), Chidambaram i wsp. (1972), Ellis (1971), Kwaśna i wsp. (1991), Malone i Muskett (1997). Zdrowotność nasion badanego gatunku trawy została wyrażona jako średnia liczba kolonii grzybowych z trzech lat zbioru i czterech odmian.

Ocenę zdolności kiełkowania wykonano zgodnie z zaleceniami ISTA (2019). Otrzymane wyniki poddano analizie statystycznej przy wykorzystaniu programu Statistica oraz wyliczono wartość NIR.

\section{Wyniki i dyskusja}

Analiza mikologiczna wykazała liczne zasiedlenie przez grzyby nasion zarówno kostrzewy łąkowej, jak i życicy trwałej. $\mathrm{Na}$ nasionach obu badanych gatunków zidentyfikowano od 36 do 39 gatunków należących do 23-26 rodzajów. Większa różnorodność gatunkowa grzybów wystąpiła na nasionach życicy trwałej. Wśród obserwowanych grzybów saprotroficznych najczęściej występowały: Alternaria alternata, Aureobasidium pullulans, Epicoccum purpurascens, Cladosporium herbarum i Penicillium spp, zaś wśród patogenów grzyby z rodzaju Bipolaris, Drechslera i Fusarium (tab. 1 i 2). Podobne grzyby były wcześniej wyizolowane i zidentyfikowane przez Kućmierza i wsp. (1992), Kutrzebę (1994 a i b), Wiewiórę i Prończuk (2000) oraz Pańkę i wsp. (2010). Najczęściej występującymi gatunkami patogenicznymi zarówno na nasionach badanych odmian kostrzewy łąkowej, jak i życicy trwałej były 4 gatunki z rodzaju Drechslera (D. dematioidea, D. dictyoides, D. siccans, D. triseptata) oraz 10 gatunków Fusarium $(F$. avenaceum, $F$. culmorum, $F$. equiseti, $F$. graminearum, $F$. oxysporum, $F$. poae, $F$. semitectum, $F$. solani, F. sporotrichoides, F. tricinctum). Najwięcej grzybów obserwowano na nasionach zaprawianych z użyciem zapraw biologicznych Bioczos i Polyversum. W tym samym czasie $\mathrm{z}$ nasion powierzchniowo odkażonych wyrosło mniej grzybów w stosunku do w/w zapraw średnio o $36-39 \%$ dla życicy i o $23-40 \%$ dla badanych odmian kostrzewy (tab. 1 i 2). Analizy statystyczne wykazały istotne zróżnicowanie liczebności grzybów w zależności od zaprawiania, odmiany i roku zbioru zarówno dla kostrzewy, jak i życicy (tab. 3 i 4, rys. 2a i 3a). Najczęściej izolowanym gatunkiem spośród wszystkich zidentyfikowanych zarówno dla nasion kostrzewy, jak i życicy był saprotrof 
Alternaria alternata, który wystąpił w zależ- trwałej oraz 12,2-43,1\% wszystkich wyizolowaności od kombinacji na poziomie 12,5 - 66,4\% nych grzybów u kostrzewy łąkowej (tab. 1 i 2). wszystkich wyizolowanych grzybów u życicy

Wyizolowane z nasion kostrzewy ląkowej gatunki grzybów (średnia z trzech lat i czterech odmian).

The fungi species isolated from the seeds of meadow fescue (average of three years and four cultivars).

\begin{tabular}{|c|c|c|c|c|c|}
\hline \multirow{2}{*}{$\begin{array}{l}\text { Gatunek grzyba/ } \\
\text { Fungus species }\end{array}$} & \multicolumn{5}{|c|}{$\begin{array}{l}\text { Liczba kolonii (średnio dla odmian i lat badań) } \\
\text { Number of colonies (mean for cultivars and research years) }\end{array}$} \\
\hline & Niezaprawiane/ Untreated & Bioczos & Polyversum & Maxim & Vitavax \\
\hline Acremoniella atra & - & - & 0,17 & - & - \\
\hline Acremonium spp. & 0,16 & 0,23 & 0,07 & 0,07 & - \\
\hline Alternaria alternata & 27,93 & 40,90 & 27,20 & 5,30 & 1,00 \\
\hline Ascochyta sp. & 0,20 & 1,43 & 0,20 & 0,60 & - \\
\hline Aspergillus spp. & 0,23 & 0,03 & 0,03 & 0,73 & 0,03 \\
\hline Aureobasidium pullulans & 3,50 & 16,60 & 18,80 & 8,10 & 0,53 \\
\hline Bipolaris sorokiniana & 0,60 & 0,27 & 0,07 & - & - \\
\hline Botrytis cinerea & 0,03 & 0,17 & 0,27 & - & - \\
\hline Cladosporium herbarum & 0,47 & 3,63 & 2,73 & 3,73 & 0,07 \\
\hline Drechslera dematioidea & 0,17 & 0,07 & - & - & - \\
\hline Drechslera dictyoides & 7,87 & 2,03 & 0,60 & - & - \\
\hline Drechslera siccans & 8,87 & 5,87 & 2,67 & 0,27 & 0,23 \\
\hline Drechslera triseptata & - & 0,07 & 0,07 & - & - \\
\hline Epicocum purpurascens & 7,90 & 15,23 & 15,13 & 1,00 & 0,20 \\
\hline Fusarium avenaceum & 0,13 & 0,70 & 0,37 & - & - \\
\hline Fusarium culmorum & 0,07 & 0,63 & 0,83 & 0,23 & - \\
\hline Fusarium equiseti & 0,13 & 1,47 & 1,33 & - & - \\
\hline Fusarium graminearum & - & 0,57 & 0,20 & - & - \\
\hline Fusarium oxysporum & - & 0,07 & 0,07 & - & - \\
\hline Fusarium poae & - & 0,30 & 0,10 & - & - \\
\hline Fusarium semitectum & 0,10 & 0,37 & 0,17 & 0,23 & - \\
\hline Fusarium solani & 0,23 & 0,23 & 0,60 & 0,10 & - \\
\hline Fusarium sporotrichioides & - & 0,07 & - & - & - \\
\hline Fusarium tricinctum & - & 0,03 & 0,03 & - & - \\
\hline Microdochium spp. & 0,07 & - & - & - & - \\
\hline Mucor spp. & 0,23 & 0,87 & 0,80 & 0,60 & 0,03 \\
\hline Papularia arundinis & 0,17 & 0,37 & - & 0,23 & - \\
\hline Penicillium spp. & 2,03 & 9,43 & 13,40 & 12,47 & 5,97 \\
\hline Phoma spp. & 0,80 & 2,57 & 0,50 & 1,90 & - \\
\hline Rhizopus sp. & 0,27 & 1,33 & 1,30 & 0,63 & 0,07 \\
\hline Septoria sp. & 0,27 & 0,17 & 0,03 & 0,17 & - \\
\hline Sordaria fimicola & 0,03 & - & - & - & - \\
\hline Stemphylium botryosum & 1,03 & 0,27 & 0,17 & - & - \\
\hline Stemphylium consortiale & 0,70 & 1,60 & 0,33 & 0,10 & - \\
\hline Trichoderma viride & 0,07 & 0,10 & 0,03 & 0,03 & - \\
\hline Trichotecium roseum & - & 0,20 & - & - & - \\
\hline $\begin{array}{l}\text { grzybnia niezarodnikująca/ } \\
\text { non-sporulating mycelium }\end{array}$ & 0,53 & 0,07 & 0,07 & 0,47 & 0,07 \\
\hline Ogółem/Total & 64,79 & 107,95 & 88,41 & 36,96 & 8,20 \\
\hline
\end{tabular}

Wyniki badań Tulloch i Leach (1972) oraz Labruyere (1980) wskazują, że gatunek ten 
może służyć jako przybliżony wskaźnik jakości materiału siewnego, a także wskazuje na niekorzystne warunki pogodowe w czasie zbioru nasion. Ponadto Kućmierz i Gorajczyk (1991) stwierdzili, że A. alternata silnie hamuje kiełkowanie, ale zmniejsza ich energię kiełkowania tylko w niewielkim stopniu. Wyniki badań Zang’a i wsp. (2006) wskazują zaś, że w największym stopniu na zmniejszenie kiełkowania poprzez produkcję wtórnych metabolitów lub bezpośrednie uszkodzenie tkanek nasion wpływają Fusarium spp. i Bipolaris sorokiniana. Nasze badania nie potwierdziły tych wyników, gdyż badane przez nas odmiany i gatunki kiełkowały na poziomie $87-93 \%$, a wykonane analizy statystyczne nie wykazały istotnych różnic zarówno dla gatunków, odmian jak i badanych kombinacji. Jednocześnie należy zaznaczyć, że zastosowane zaprawy, mimo istotnych zmian w występowaniu grzybów, nie wpłynęły istotnie na zdolność kiełkowania badanych nasion (rys. 1). Grzyby z rodzaju Fusarium i Drechslera to jedne z najczęściej izolowanych $\mathrm{z}$ nasion patogenów traw (Vargas, 1994; Wiewióra i Prończuk, 2002; Wiewióra, 2012). Rezultaty naszych badań potwierdzają te doniesienia, zwłaszcza jeżeli chodzi o gatunki z rodzaju Drechslera, gdyż na nasionach niezaprawianych wystąpiły one na poziomie 18,50 kolonii/100 nasion dla kostrzewy łąkowej i 5,50 kolonii/100 nasion dla życicy trwałej. Obserwowano istotne różnice pomiędzy odmianami obu gatunków traw: średnio u kostrzew od 3,40 kolonii/100 nasion dla odmiany Fantazja do 8,87 kolonii/100 nasion dla Artemy i dla życic od 0,53 kolonii/100 nasion u odmiany Flinston do 4,27 kolonii/100 nasion dla Reli. Również występowanie tych grzybów było zróżnicowane $\mathrm{w}$ zależności od roku zbioru i wynosiło od 3,20 do 11,45 kolonii/100 nasion dla kostrzewy $\mathrm{i}$ od 1,90 do 2,05 kolonii/100 nasion dla życicy (tab. 3 i 4). Jednocześnie należy podkreślić, że wszystkie zastosowane zaprawy wpłynęły na znaczne zmniejszenie porażenia nasion przez te grzyby dla obu badanych gatunków w stosunku do nasion odkażanych powierzchniowo (rys. $2 \mathrm{~b}$ i $3 b$ ).

Grzyby z rodzaju Fusarium wystąpiły na dużo niższym poziomie, (średnio dla nasion niezaprawianych 0,92 kolonii/100 nasion u kostrzewy i 2,67 kolonii/100 nasion kolonii u życicy). Efektywność zaprawiania w stosunku do tych patogenów była widoczna tylko w przypadku zapraw chemicznych (tab. 3 i 4, rys. 2c i 3c). Najwyższą frekwencję występowania tych grzybów obserwowano na nasionach zaprawionych przy użyciu zapraw biologicznych. Na nasionach kostrzewy ich liczebność wzrosła do 4,58 kolonii/100 nasion dla zaprawy Polyversum i do 5,75 kolonii/100 nasion w przypadku Bioczosu. Podobna zależność była obserwowana dla nasion życicy, gdzie również nastąpił wzrost liczebności tych grzybów, tylko w tym przypadku, więcej ich zidentyfikowano po zastosowaniu zaprawy Polyversum (średnio 6,75 kolonii/100 nasion) $\mathrm{W}$ porównaniu do Bioczosu (średnio 6,42 kolonii/100 nasion) (tab. 3 i 4). Również dla tych grzybów obserwowano istotne różnice pomiędzy odmianami obu gatunków traw: średnio u kostrzew od 0,60 kolonii/100 nasion dla odmiany Wanda do 5,60 kolonii/100 nasion dla Fantazji i dla życic od 1,87 kolonii/100 nasion u odmiany Baronka do 5,40 kolonii/100 nasion dla odmiany Flinston. Występowanie Fusarium spp. także było zróżnicowane w zależności od roku zbioru i wynosiło od 0,85 do 5,00 kolonii/100 nasion dla kostrzewy i od 0,30 do 7,55 kolonii/100 nasion dla życicy (tab. 3 i 4).

Przeprowadzone analizy zdrowotności nasion obu gatunków traw wskazują, że zastosowane zaprawy chemiczne Maxim i Vitavax były efektywne $\mathrm{w}$ hamowaniu rozwoju grzybów, w tym głównych patogenów traw, co potwierdzają badania dla innych zapraw wykonane przez Falloon'a (1980). Badane zaprawy biologiczne były mniej skuteczne w zmniejszeniu liczebności grzybów, w tym głównych patogenów oraz poprawie zdolności kiełkowania w stosunku do zapraw chemicznych.

Zastosowane na nasionach kostrzewy preparaty wykazały statystycznie istotny wpływ na liczebności kolonii Bipolaris i Drechslera, a najwyższą efektywnością wykazały się Maxim i Vitavax. Najwięcej grzybów, w tym również gatunków z rodzaju Fusarium obserwowano na nasionach zaprawianych preparatami Bioczos oraz Polyversum. Statystycznie istotne różnice w liczebności kolonii Fusarium spp. w stosunku do obu tych preparatów zanotowano po zastosowaniu zapraw chemicznych Maxim i Vitavax (tab. 3).

Wszystkie zastosowane preparaty na nasionach życicy wykazały statystycznie istotny wpływ na liczebność kolonii Bipolaris i Drechslera w stosunku do nasion niezaprawianych, przy czym działanie preparatu chemicznego Vitavax ograniczało w sposób istotny również ich ilość w stosunku 
do preparatu Bioczos. Badania wykazały także liczba kolonii grzybów była również najwyższa istotne statystycznie różnice w przypadku licz- po zastosowaniu preparatów Bioczos oraz Polyverby kolonii Fusarium. Na nasionach życicy ogólna sum (tab.4).

Tabela 2

Table 2

Wyizolowane z nasion życicy trwałej gatunki grzybów (średnia z trzech lat i czterech odmian).

The fungi species isolated from the seeds of meadow fescue (average of three years and four cultivars).

\begin{tabular}{|c|c|c|c|c|c|}
\hline \multirow{2}{*}{$\begin{array}{l}\text { Gatunek grzyba/ } \\
\text { Fungus species }\end{array}$} & \multicolumn{5}{|c|}{$\begin{array}{l}\text { Liczba kolonii (średnio dla odmian i lat badań) } \\
\text { Number of colonies (mean for cultivars and research years) }\end{array}$} \\
\hline & Niezaprawiane/ Untreated & Bioczos & Polyversum & Maxim & Vitavax \\
\hline Acremoniella atra & 0,10 & 0,53 & - & - & - \\
\hline Acremonium spp. & 0,07 & 0,10 & 0,10 & - & - \\
\hline Alternaria alternata & 48,00 & 48,03 & 40,17 & 22,30 & 3,23 \\
\hline Arthrobotrys superba & - & 0,13 & 0,13 & - & - \\
\hline Ascochyta sp. & 0,07 & - & 0,03 & 0,03 & - \\
\hline Aspergillus spp. & 0,07 & 0,07 & 0,43 & - & 0,03 \\
\hline Aureobasidium pullulans & 1,53 & 9,83 & 12,53 & 4,50 & 0,27 \\
\hline Bipolaris sorokiniana & 0,13 & 0,20 & - & - & 0,03 \\
\hline Botrytis cinerea & - & 0,67 & 0,87 & 0,03 & - \\
\hline Cladosporium herbarum & 0,67 & 1,27 & 1,00 & 1,90 & 0,03 \\
\hline Drechslera dematioidea & 0,27 & 0,07 & - & - & - \\
\hline Drechslera dictyoides & 1,07 & - & - & - & - \\
\hline Drechslera siccans & 3,33 & 1,97 & 1,53 & 0,47 & 0,13 \\
\hline Drechslera triseptata & 0,07 & 0,03 & - & 0,10 & - \\
\hline Epicocum purpurascens & 7,93 & 19,10 & 16,67 & 3,67 & 1,20 \\
\hline Fusarium avenaceum & 0,57 & 0,47 & 0,77 & - & 0,13 \\
\hline Fusarium culmorum & 0,43 & 0,90 & 1,20 & 0,43 & 0,10 \\
\hline Fusarium equiseti & 0,27 & 0,93 & 1,07 & 0,20 & - \\
\hline Fusarium graminearum & 0,33 & 1,07 & 1,43 & 0,27 & 0,03 \\
\hline Fusarium oxysporum & 0,20 & 0,60 & 0,13 & - & - \\
\hline Fusarium poae & 0,20 & 0,27 & 0,07 & - & - \\
\hline Fusarium semitectum & - & 0,37 & 0,60 & 0,10 & - \\
\hline Fusarium solani & 0,63 & 0,93 & 1,13 & 0,27 & - \\
\hline Fusarium sporotrichioides & 0,03 & - & 0,13 & 0,03 & - \\
\hline Fusarium tricinctum & - & 0,20 & 0,07 & - & - \\
\hline Mucor spp. & 0,20 & 1,67 & 1,97 & 1,13 & 0,10 \\
\hline Microdochium spp. & 0,27 & 0,13 & 0,10 & 0,10 & - \\
\hline Papularia arundinis & 0,40 & 0,50 & 0,93 & 0,10 & - \\
\hline Penicillium spp. & 1,87 & 24,27 & 25,50 & 26,00 & 20,33 \\
\hline Pestalotia sp. & - & - & 0,07 & - & - \\
\hline Phoma spp. & 0,43 & 1,17 & 1,27 & 1,93 & 0,03 \\
\hline Rhizoctonia solani & 0,13 & 0,13 & 0,13 & - & - \\
\hline Rhizopus sp. & 0,10 & 2,13 & 2,13 & 0,80 & - \\
\hline Septonema chaetospira & 0,93 & 0,13 & - & - & - \\
\hline Septoria sp. & 0,03 & 0,07 & - & - & - \\
\hline Sordaria fimicola & 0,17 & 0,03 & - & - & - \\
\hline Stemphylium botryosum & 0,30 & 0,10 & - & - & - \\
\hline Stemphylium consortiale & 1,43 & 0,90 & 0,70 & 0,63 & 0,10 \\
\hline Trichoderma viride & - & 0,13 & - & 0,10 & - \\
\hline
\end{tabular}




\begin{tabular}{cccccc}
$\begin{array}{c}\text { grzybnia niezarodnikująca/ } \\
\text { non-sporulating mycelium }\end{array}$ & 0,07 & 0,17 & 0,17 & 0,33 & - \\
\hline Ogółem/Total & 72,30 & 119,27 & 113,03 & 65,42 & 25,74 \\
\hline
\end{tabular}

Tabela 3

Table 3

Analiza wariancji dla wybranych grzybów zasiedlających nasiona kostrzewy ląkowej (Festuca pratensis).

Analysis of variance for some fungi infected seeds of meadow fescue (Festuca pratensis).

\begin{tabular}{|c|c|c|c|c|c|c|c|}
\hline \multicolumn{2}{|r|}{ Czynnik } & \multicolumn{2}{|c|}{ Fusarium } & \multicolumn{2}{|c|}{ Bipolaris i Drechslera } & \multicolumn{2}{|c|}{ Grzyby/Fungi } \\
\hline & & Średnie/Mean & $\begin{array}{l}\text { Odch. std/ } \\
\text { Std. dev. }\end{array}$ & Średnie/Mean & $\begin{array}{l}\text { Odch. std/ } \\
\text { Std. dev. }\end{array}$ & Średnie/Mean & $\begin{array}{l}\text { Odch. std/ } \\
\text { Std. dev. }\end{array}$ \\
\hline \multirow{5}{*}{ 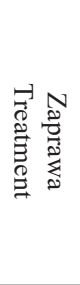 } & $\begin{array}{c}\text { Niezaprawiane/ } \\
\text { Untreated }\end{array}$ & $0,92 \mathrm{a}$ & 2,04 & $18,50 \mathrm{~d}$ & 16,34 & $67,79 \mathrm{c}$ & 30,91 \\
\hline & Bioczos & $5,75 \mathrm{~b}$ & 8,45 & $8,50 \mathrm{c}$ & 10,15 & $112,75 \mathrm{e}$ & 25,28 \\
\hline & Polyversum & $4,58 \mathrm{~b}$ & 9,33 & $3,75 b$ & 4,66 & $92,96 \mathrm{~d}$ & 39,22 \\
\hline & Maxim & $1,00 \mathrm{a}$ & 4,49 & $0,25 \mathrm{a}$ & 0,68 & $33,58 b$ & 25,78 \\
\hline & Vitavax & $0,00 \mathrm{a}$ & 0,00 & $0,25 \mathrm{a}$ & 0,68 & $7,58 \mathrm{a}$ & 14,99 \\
\hline \multicolumn{2}{|c|}{$\mathrm{NIR} / \mathrm{LSD} \alpha=0,05$} & 1,61 & & 3,15 & & 5,05 & \\
\hline \multirow{4}{*}{ 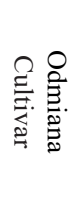 } & Fantazja & $5,60 \mathrm{c}$ & 11,30 & $3,40 \mathrm{a}$ & 5,54 & $55,70 \mathrm{a}$ & 39,32 \\
\hline & Wanda & $0,60 \mathrm{a}$ & 1,40 & $8,67 \mathrm{~b}$ & 13,32 & $61,80 \mathrm{~b}$ & 47,48 \\
\hline & Pasja & $2,13 b$ & 3,60 & $4,07 \mathrm{a}$ & 5,72 & $68,03 \mathrm{c}$ & 50,78 \\
\hline & Artema & $1,47 \mathrm{ab}$ & 3,01 & $8,87 \mathrm{~b}$ & 15,40 & $66,20 \mathrm{bc}$ & 52,77 \\
\hline \multicolumn{2}{|c|}{$\mathrm{NIR} / \mathrm{LSD} \alpha=0,05$} & 1,44 & & 2,82 & & 4,52 & \\
\hline \multirow{3}{*}{$\underset{ه}{\stackrel{0}{\pi}}$} & 2014 & $5,00 \mathrm{~b}$ & 9,98 & $3,20 \mathrm{a}$ & 7,66 & $53,05 \mathrm{a}$ & 44,18 \\
\hline & 2015 & $0,85 \mathrm{a}$ & 1,80 & $11,45 b$ & 15,49 & $56,45 \mathrm{a}$ & 45,17 \\
\hline & 2016 & $1,50 \mathrm{a}$ & 3,26 & $4,10 \mathrm{a}$ & 5,87 & $79,30 \mathrm{~b}$ & 49,74 \\
\hline \multicolumn{2}{|c|}{ NIR/LSD $\alpha=0,05$} & 1,25 & & 2,44 & & 3,91 & \\
\hline
\end{tabular}

Tabela 4

Analiza wariancji dla wybranych grzybów zasiedlających nasiona życicy trwałej (Lolium perenne).

Table 4

Analysis of variance for some fungi infected seeds of perennial ryegrass (Lolium perenne).

\begin{tabular}{|c|c|c|c|c|c|c|c|}
\hline \multirow{2}{*}{\multicolumn{2}{|c|}{ Czynnik }} & \multicolumn{2}{|c|}{ Fusarium } & \multicolumn{2}{|c|}{ Bipolaris i Drechslera } & \multicolumn{2}{|c|}{ Grzyby/Fungi } \\
\hline & & $\begin{array}{l}\text { Średnie/ } \\
\text { Mean }\end{array}$ & $\begin{array}{l}\text { Odch. std/ } \\
\text { Std. dev. }\end{array}$ & $\begin{array}{l}\text { Średnie/ } \\
\text { Mean }\end{array}$ & $\begin{array}{l}\text { Odch. std/ } \\
\text { Std. dev. }\end{array}$ & $\begin{array}{l}\text { Średnie/ } \\
\text { Mean }\end{array}$ & $\begin{array}{l}\text { Odch. std/ } \\
\text { Std. dev. }\end{array}$ \\
\hline \multirow{5}{*}{ 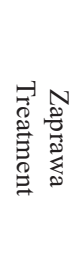 } & $\begin{array}{c}\text { Niezaprawiane/Un- } \\
\text { treated }\end{array}$ & $2,67 b$ & 4,20 & $5,50 \mathrm{c}$ & 3,45 & $71,92 b$ & 40,65 \\
\hline & Bioczos & $6,42 \mathrm{c}$ & 8,30 & $2,17 b$ & 3,73 & $120,75 \mathrm{~d}$ & 23,08 \\
\hline & Polyversum & $6,75 \mathrm{c}$ & 9,25 & $1,08 \mathrm{a}$ & 2,36 & $113,25 \mathrm{c}$ & 26,44 \\
\hline & Maxim & $0,92 \mathrm{a}$ & 2,12 & $0,75 \mathrm{a}$ & 1,94 & $66,58 b$ & 46,58 \\
\hline & Vitavax & $0,25 \mathrm{a}$ & 0,68 & $0,42 \mathrm{a}$ & 1,18 & $36,88 \mathrm{a}$ & 36,66 \\
\hline \multicolumn{2}{|c|}{$\mathrm{NIR} / \mathrm{LSD} \alpha=0,05$} & 1,69 & & 0,94 & & 5,64 & \\
\hline \multirow{4}{*}{ 尺 } & Flinston & $5,40 \mathrm{c}$ & 9,41 & $0,53 a$ & 1,17 & $86,33 b$ & 55,11 \\
\hline & Baronka & $1,87 \mathrm{a}$ & 3,15 & $1,47 b$ & 2,78 & $91,87 \mathrm{c}$ & 43,01 \\
\hline & Rela & $3,73 b$ & 5,19 & $4,27 \mathrm{c}$ & 4,06 & $65,70 \mathrm{a}$ & 46,77 \\
\hline & Malowana & $2,60 \mathrm{ab}$ & 6,17 & $1,67 \mathrm{~b}$ & 3,11 & $83,60 \mathrm{~b}$ & 40,24 \\
\hline \multicolumn{2}{|c|}{ NIR/LSD $\alpha=0,05$} & 1,51 & & 0,84 & & 5,05 & \\
\hline
\end{tabular}


BIULETYN IHAR Nr 294 / 2021

Ocena zdrowotności materiału nasiennego traw w zależności od wybranych zapraw nasiennych

\begin{tabular}{|c|c|c|c|c|c|c|c|}
\hline \multirow{3}{*}{$\underset{\circledR}{\overparen{0}}$} & 2014 & $7,55 \mathrm{c}$ & 8,87 & 2,05 & 2,46 & $98,33 \mathrm{c}$ & 34,76 \\
\hline & 2015 & $2,35 b$ & 4,37 & 2,00 & 3,39 & $89,20 \mathrm{~b}$ & 46,66 \\
\hline & 2016 & $0,30 \mathrm{a}$ & 0,85 & 1,90 & 3,81 & $58,10 \mathrm{a}$ & 49,63 \\
\hline & $\alpha=0,05$ & 1,31 & & ni & & 4,37 & \\
\hline
\end{tabular}

Rys. 1. Zdolność kiełkowania materiału siewnego kostrzewy ląkowej i życicy trwałej w zależności od zastosowanej zaprawy nasiennej.

Fig. 1. Germination capacity of the seeds of meadow fescue and perennial ryegrass depending on the applied seed treatment.

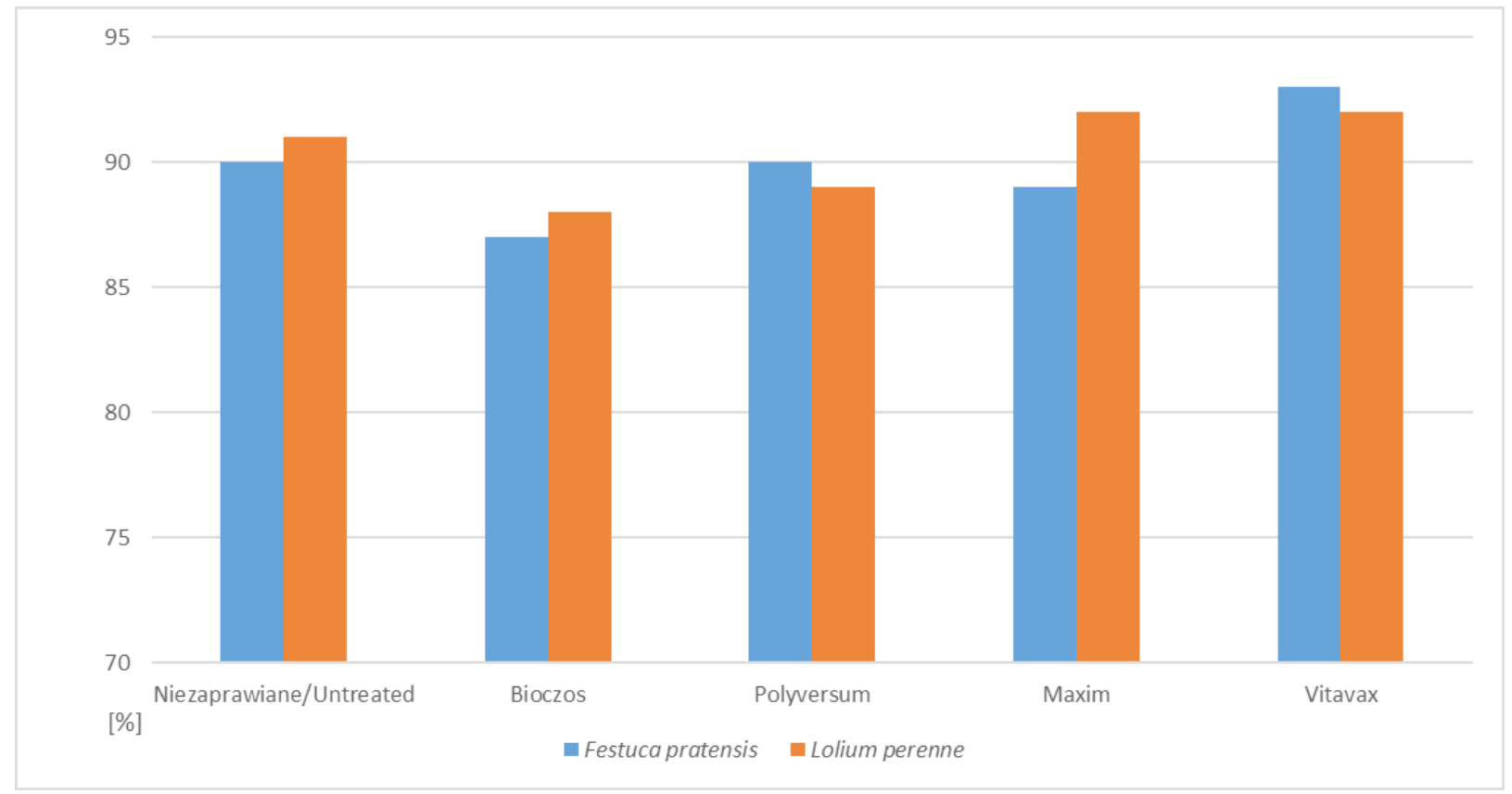

Rys. 2. Występowanie grzybów (a), gatunków z rodzaju Fusarium (b), Bipolaris i Drechslera (c) wyizolowanych z nasion kostrzewy ląkowej (Festuca pratensis) dla odmian i lat zbioru w zależności od zastosowanej zaprawy nasiennej (średnia liczba kolonii/100 nasion).

Fig. 2. Occurrence of fungi (a), species of the genera Fusarium (b), Bipolaris and Drechslera (c), isolated from the seeds of the meadow fescue (Festuca pratensis) for cultivars and year of harvest depending on used the seed treatment (mean number of colonies/100 seeds).

N-niezaprawiane/untreated, B-Bioczos, P-Polyversum, M-Maxim, V-Vitavax

a)

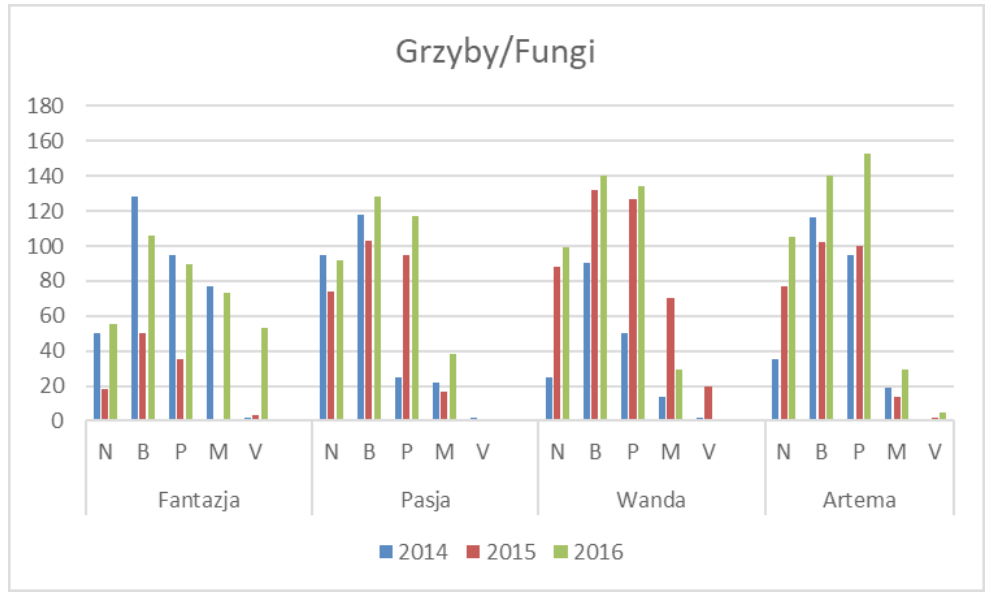

b) 


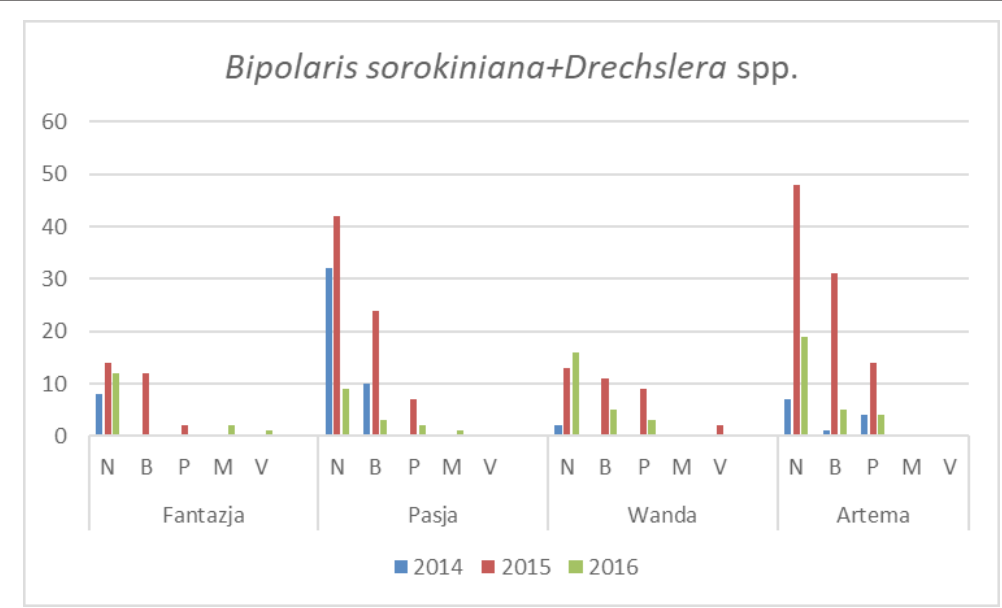

c)

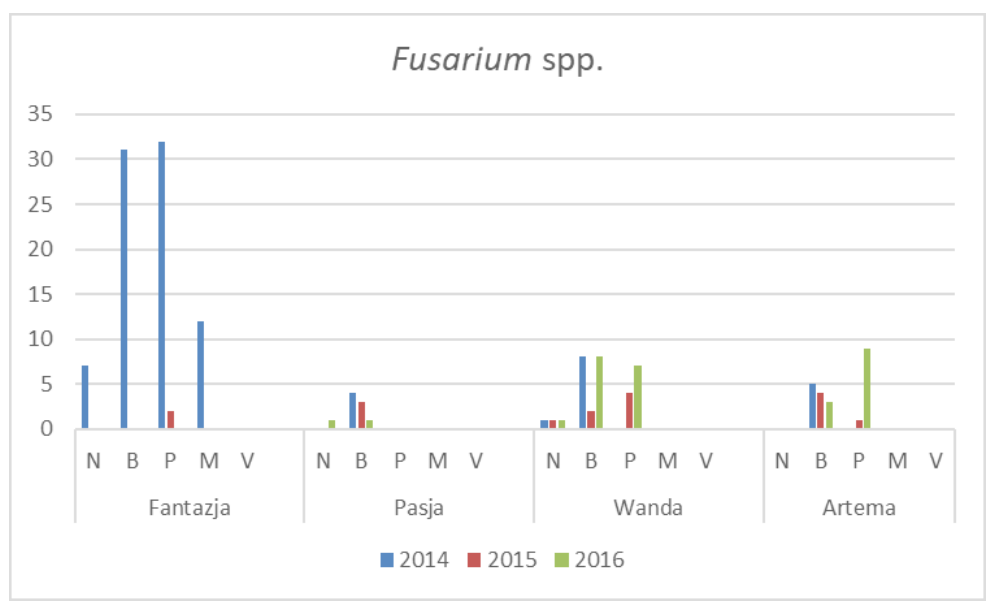

Rys. 3. Występowanie grzybów (a), gatunków z rodzaju Fusarium (b), Bipolaris i Drechslera (c) wyizolowanych z nasion życicy trwałej (Lolium perenne) dla odmian i lat zbioru w zależności od zastosowanej zaprawy nasiennej (średnia liczba kolonii/100 nasion).

Fig. 3. Occurrence of fungi (a), species of the genera Fusarium (b), Bipolaris and Drechslera (c), isolated from the seeds of the perennial ryegrass (Lolium perenne) for cultivars and year of harvest depending on used the seed treatment (mean number of colonies/100 seeds).

N-niezaprawiane/untreated, B-Bioczos, P-Polyversum, M-Maxim, V-Vitavax

a)

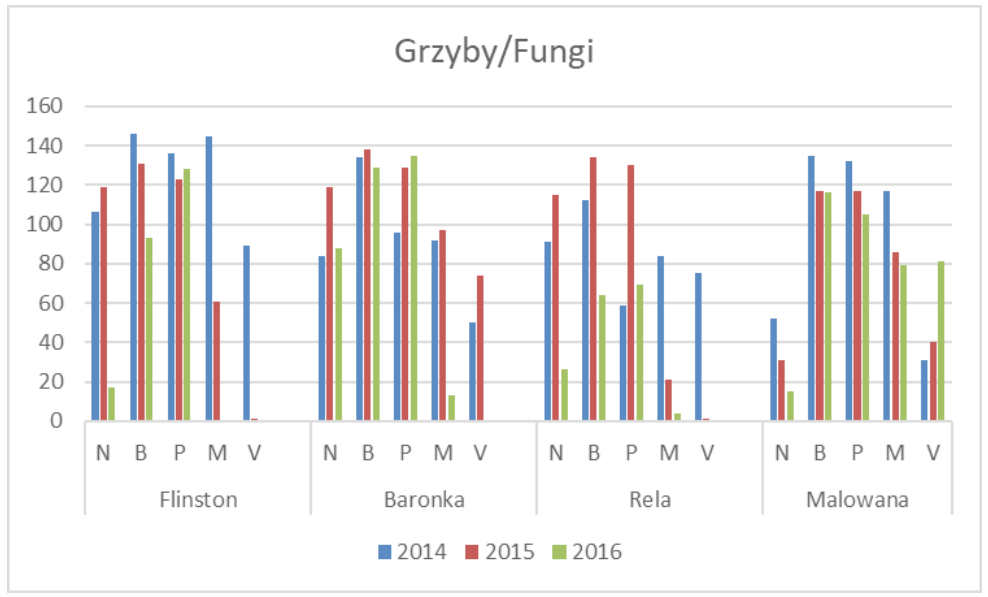


b)

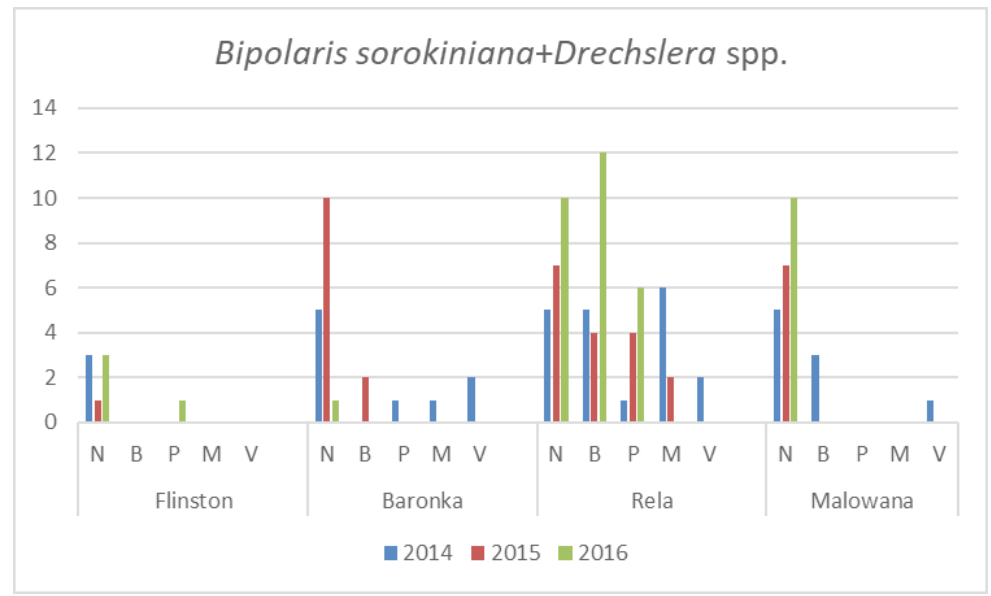

c)

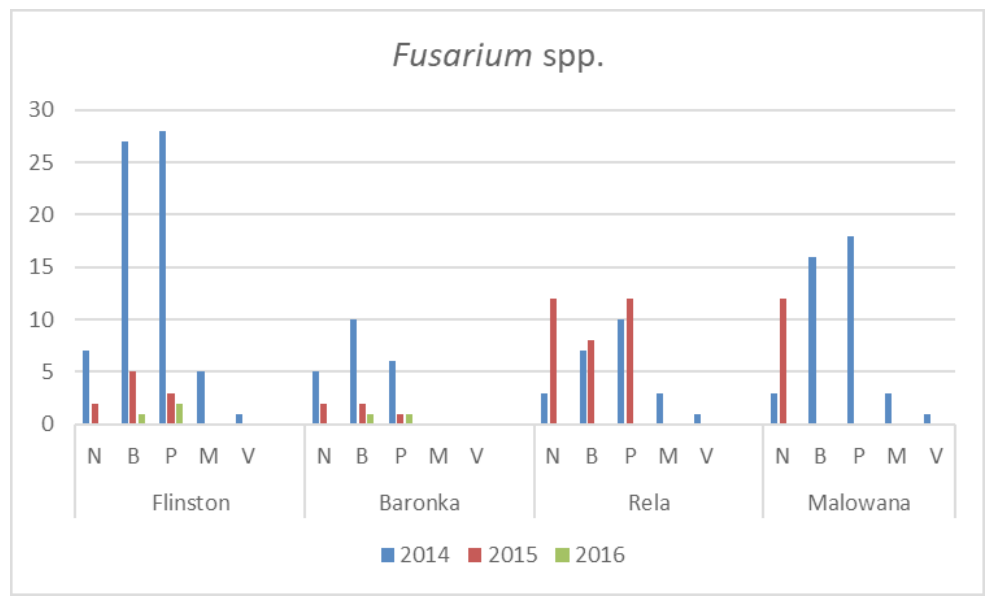

Wśród badanych preparatów najlepsze działanie w przypadku obu badanych gatunków traw wykazał Maximi Vitavax. Bioczos oraz Polyversum stanowią alternatywę dla upraw ekologicznych, obserwuje się przy ich stosowaniu spadek liczby kolonii Bipolaris i Drechslera. Nie wykazują one jednak takiego wpływu na liczebność grzybów z rodzaju Fusarium, jaki obserwowano dla zapraw chemicznych.

\section{Wnioski}

1. Materiał siewny kostrzewy łąkowej i życicy trwałej zasiedlały liczne grzyby, zarówno saprotrofy, jak i patogeny. Dominującym gatunkiem na badanym materiale siewnym był gatunek Alternaria alternata, powszechnie izolowany z nasion różnych gatunków roślin rolniczych.

2. Na nasionach kostrzewy łąkowej i życicy trwałej spośród patogenów występowały głównie gatunki należące do rodzaju Drechslera i Fusarium.

3. Korzystnie na zdrowotność nasion badanych gatunków traw wpływały zastosowane zaprawy chemiczne Maxim i Vitavax. Zaprawy biologiczne Bioczos i Polyversum nie wpłynęły na zmniejszenie liczebności grzybów wyizolowanych $\mathrm{z}$ nasion $\mathrm{w}$ stosunku do grzybów obserwowanych na nasionach powierzchniowo odkażanych, jak i zaprawianych zaprawami chemicznymi.

\section{Literatura}

Barnett, H. L. (1960). Illustrated genera of imperfect fungi. Burgess Pub. Company. Minneapolis: 1-225.

Chidambaram, S. B., Matur, S. B., Neergaard, P. (1972). Handbook on seed health testing. The International Seed Testing Association As-NLH. Norway: 1-207.

Di Menna, M. E., Lauren, D. R., Poole, P. R., Mortimer, P. H., Hill R. A., Agnew M. P. (1987). Zearalenone in New Zealand pasture herbage and the mycotoxin-producing potential of Fusarium species from pasture. N. Z. J. Agric. Res. 30:499.

Di Menna, M. E., Lauren, D. R., Sprosen, J. M., MacLean, K. S. (1991). Fusarium and zearalenone on herbage fractions from short and from long pasture. N. Z. J. Agric. Res. 34:445. 
Ellis, M. B. (1971). „Dematiaceous Hyphomycetes“. Commonwealth Mycological Institute. Kew, Surrey, England.

Falloon, R. E. (1980). Seedling emergence responses in ryegrasses (Lolium spp.) to fungicide seed treatments. New Zealand Journal of Agricultural Research, 23, 385-391.

Forsberg, G., Kristensen, L., Eibel, P., Titone, P., Haiti, W. (2003). Sensitivity of cereal seeds to short duration treatment with hot, humid air. Journal of Plant Disease and Protection, 110 (1): 1-16.

International Rules for Seed Testing. Edition 2019. Published by The International Seed Testing Association (ISTA), P. O. BOX 308, 8303 Bassersdorf, CH-Switzerland.

Kumar, S. (2012). Cultural approaches for plant disease management. Research \& Reviews: Journal of Agricultural Science and Technology, 1 (2): 12-21.

Kućmierz, J., Gorajczyk ,S., (1991) Pathogenicity of fungi isolated from sowing material of perennial ryegrass (Lolium perenne L.) for germinating caryopses and seedlings. Phytopathol. Pol. 13, 1: 62-65.

Kućmierz, J., Mazur, S., Nocoń, J., (1992) Mikoflora materiału siewnego kostrzewy łąkowej (Festucapratensis Huds.) oraz patogeniczność wybranych gatunków grzybów dla siewek in vitro. Zesz. Nauk. AR Krak. 265, Roln. 30: $151-159$.

Kutrzeba, M., (1994 a) Występowanie grzybów z rodzaju Bipolaris i Drechslera na nasionach Festuca pratensis Huds. Biul. Inst. Hod. Aklim. Rośl. 192: 107-112.

Kutrzeba, M. (1994 b). Występowanie grzybów patogenicznych na gatunkach traw z rodzaju Festuca Huds. Biul. IHAR 192: 113-121.

Kwaśna, H., Chełkowski, J., Zajkowski, P. (1991). Flora Polska T. XXII. Grzyby niedoskonałe. Strzępczakowe. Gruzełkowate. Sierpik (Fusarium) PAN Warszawa-Kraków: 1-158.

Labruyere, R. E., (1980): Fungal diseases of grasses grown for seed. In: Seed production. Ed. P.D. Hebblethwaite. Butterworths, London, pp. 173-187.

Malone, J. P., Muskett, A. E. (1997). Seed-borne fungi. Description of 77 fungus species. $3^{\text {rd }}$ Edition. Sheppard, J.
W. (ed.). ISTA, Zurich: 1-191.

Pańka, D., Jeske, M., Szczepanek, M., (2010). Effect of fungicidal control of Festuca rubra L. ssp. Commutate and F. rubra L. ssp. rubra on seed infection with fungi. In: Grassland in a changing world. Book of abstracts 23th General Meeting EGF. Kiel, Germany; August 29th-September 2nd 2010. AGGF, Kiel: 93.

Prończuk, M. (1996). Główne choroby traw w Polsce. Biul. IHAR 199: 157-169.

Sharma, K. K., Singh, U. S., Sharma, P., Kumar, A., Sharm, L. (2015). Seed treatments for sustainable agriculture -A review. Journal of Applied and Natural Science 7 (1): 521-539.

Smith, J. F., Di Menna, M. E., McGowan, L. T. (1990). Reproductive performance of Coopworth ewes following oral doses of zearalenone before and after mating. J. Reprod. Fertil. 89:99.

StatSoft, Inc. (2014). STATISTICA (data analysis software system), version 12. www.statsoft.com.

Tulloch, M., Leach, C. M., (1972): A world-wide survey of the microflora of Dactylis glomerata seed. Ann. Appl. Biol. 72: 145-154.

Vargas, J. M. (1994). Management of turfgrass diseases. pp. 1-294 in Lewis Publ. CPR Press, Inc.

Wiewióra, B. (2012). The effect of seed health of perennial ryegrass (Lolium perenne L.) on germination capacity. Plant Breeding and Seed Science 65, 51-62.

Wiewióra, B., Prończuk, M., (2000). Mikroorganizmy zasiedlające nasiona traw i ich wpływ na występowanie chorób w uprawie trawnikowej. Biul. Inst. Hod. Aklim. Rośl. 214: 269-284.

Wiewióra, B., Prończuk, M. (2002). Rhizoctonia solani and other fungi detected in perennial ryegrass seeds after harvest and storage. Phytopathologia Polonica 26, 19-27.

Zang, Y. Han, J. G. Bolkan, H. Shi, Q. H. (2006). The mycoflora of perennial ryegrass and their effects on the germination and seedling vigour. Seed Science and Technology 34, 429-441. 